\title{
Identification of land reclamation area and potential plantation area on Bagmati river-basin in the Terai region of Nepal
}

\begin{abstract}
A. K. Acharya ${ }^{1 *}$, A. K. Chaudhary ${ }^{1}$ and S. Khanal ${ }^{1}$
Utilization of land reclamation area offers the potentiality of increasing greenery as well as providing forest products. This study refers to the identification of the land reclamation areas and potential plantation areas on the Bagmati river-basin in the Terai region of Nepal, and recommends appropriate species for plantation in order to rehabilitate such areas. Multi-temporal Landsat Satellite Images (Landsat 7 and Landsat 8) were acquired for 2002 and 2014. Object-based Image Classification method was used to classify the land cover classes into four broad categories: i) Water, ii) Sand and gravel, iii) Plantation potential (open areas suitable for plantation) and iii) Others (forest, agriculture, built-up areas etc.). The Mean Normalized Difference Water Index (NDWI) values and Mean Brightness values were found to be helpful in identifying the water and sand \& gravel areas from the other land cover classes. The overall classification accuracy was 0.97 with a kappa coefficient of 0.89 in the case of the 2014 Image classification. In this study, the land reclamation area referred to the areas occupied by water, sand \& gravel on the river-beds that were converted into plantation potential and other classes between 2002 and 2014. Similarly, the potential plantation area referred to the summation of the area of reclaimed land, the area of 'Others' class converted into 'Plantation potential' class and the area that remained to be plantation potential on the bed of the Bagmati River and its tributaries between 2002 and 2014. Altogether, 4,819.10 ha land was reclaimed in the study area, and a total of 5,395.10 ha land was found to be potential for plantation within the study area.
\end{abstract}

Key words: Bagmati river basin, land reclamation, object-based image classification, potential plantation area, Terai

$\mathrm{L}$ and use and land cover data are essential for planners, decision makers and managers for natural resources management. Up-to-date land use and land cover information are required for monitoring and analysis of natural resources to support their sustainable management (Xian, 2009). Remote Sensing and Geographic Information System (GIS) techniques have been recognized as an effective tool for the classification of land use and land cover data and assessment of trend, rate, nature, location and magnitude of the changes (Adeniyi et al., 1999). The remote sensing technology has offered a wide variety of satellite imagery that covers most of the earth's surface. The multi-sensor and multitemporal satellite data is a promising tool for producing accurate land cover maps (Yoon et al., 2004). Water resources assessment and coastal management $(\mathrm{Xu}, 2006)$ is one of the many field of applications of remotely sensed imagery.
Land reclamation area is, in general, the land created by river after changing its course. In Nepal, most of the rivers debouch into the Terai plains at the foot hills of the Churia, and provide water for livelihood of the people living in the Terai. During the monsoon months from June to September, all these rivers get inundated with bank-full discharges, and cause flooding in several parts of the Terai. Most of the rivers in the Terai are prone to change their course frequently. In many cases, these rivers find new paths, and enter into the cultivated lands leaving the old courses (Adhikari, 2013).

Most of the flooded river-side areas are in unutilized state due to low availability of nutrients in the sandy soil. Plantation could be a better option to manage such land reclamation areas. It will be helpful to fulfill the growing demand for forest products of the local people. It will not only

\footnotetext{
Department of Forest Research and Survey, Kathmandu, Nepal

* Email: acharya.amulkumar@gmail.com
} 
provide goods but also several ecosystem services such as landscape beauty, carbon sequestration, water table recharge, creation of wildlife habitat, prevention of river-bank erosion and so on.

The Government of Nepal has recently promulgated "Forest Policy 2015" which emphasizes on plantation program in forest as well as public and private lands. The Ministry of Forests and Soil Conservation (MoFSC) expends its fund in plantation activities through its departments. Recently, the MoFSC has declared "forest decade program (2014-2023)" for growing greenery through massive plantation. Thus, land reclamation area will be potential sites for plantation to support the forest decade program.

So far, no adequate number of GIS-based studies that deal with identification and mapping of the land reclaimed areas have been conducted in Nepal. Therefore, study on land reclamation has great importance for future plantation activities. The objectives of this study were to identify the land reclamation areas and the potential plantation areas on the Bagmati river-basin in the Terai region, and recommend appropriate species for plantation in order to rehabilitate such areas.

\section{Materials and methods}

\section{Study area}

The study was confined to the Bagmati riverbasin in the Terai physiographic region (Fig. 1). Geographically, the study area extends from $26^{\circ} 44^{\prime} 30^{\prime \prime} \mathrm{N}$ to $27^{\circ} 12^{\prime} 22^{\prime \prime} \mathrm{N}$ latitude and from $85^{\circ} 15^{\prime} 59^{\prime \prime} \mathrm{E}$ to $85^{\circ} 34^{\prime} 02^{\prime \prime} \mathrm{E}$ longitude. It includes 34 Village Development Committees (VDCs) of Rautahat district and 37 VDCs of Sarlahi district, and covers $61,279.78$ ha area.

The Bagmati River originates from the Midhills (Shivapuri hill situated in the north of the Kathmandu Valley), and drains the Gangetic plain flowing across the Mahabharat range and the Churia hills. It covers an area of $3,640 \mathrm{~km}^{2}$. The basin of this river, thus, transects three distinct latitudinal physiographic zones viz. Mountain, Siwalik and Terai of Nepal (Paudel, 2001). The study was conducted in February to June 2015.

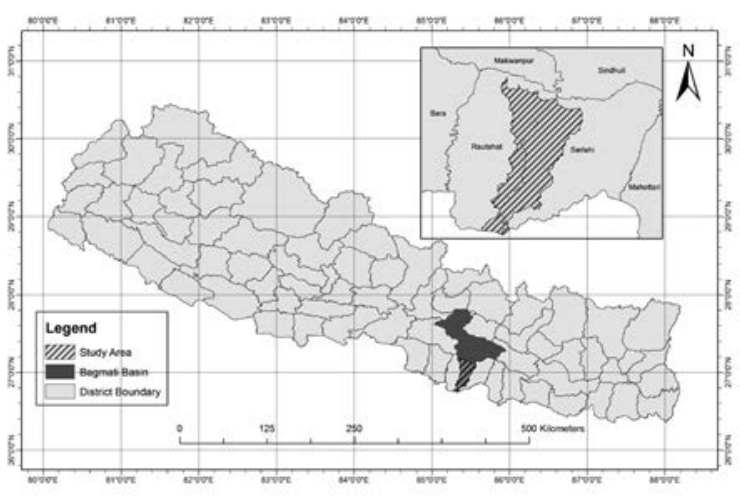

Fig. 1: Map showing the location of the study area

\section{Methods}

The methodology used in this study is highlighted in Fig. 2. The data analysis steps are explained in the subsequent sections.

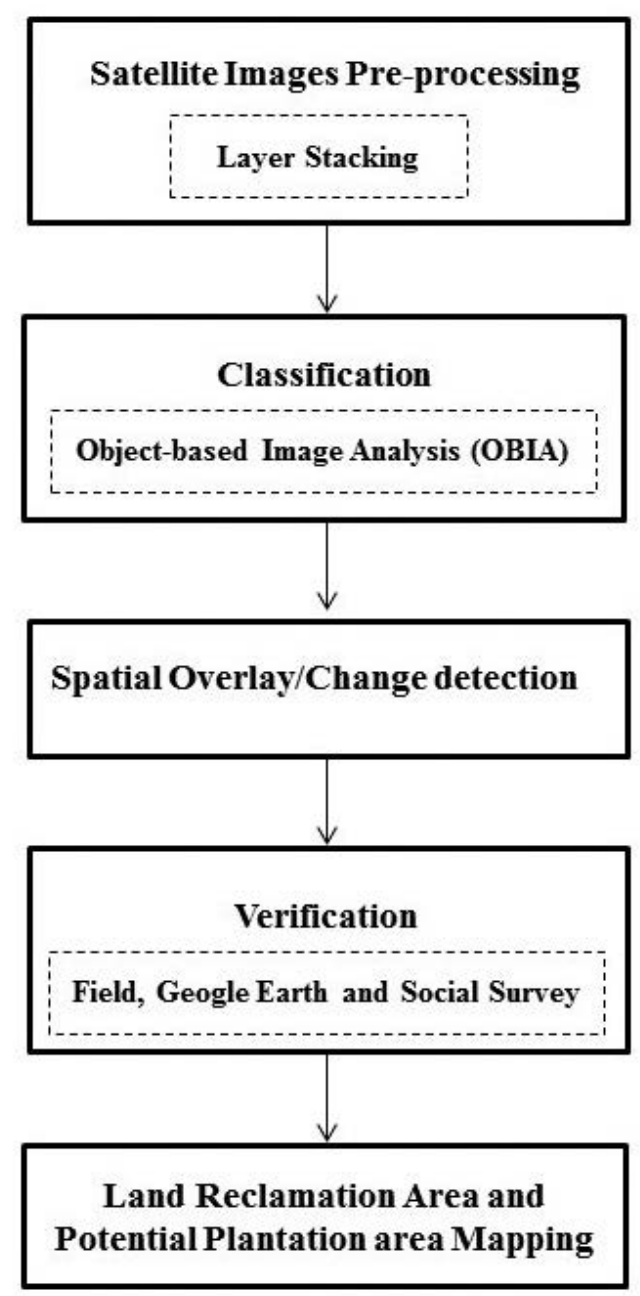

Fig. 2: Flow chart of methodology 


\section{Data}

The multi-temporal satellite imageries of Landsat 7 (ETM+) and Landsat 8 were used for the purpose of the study (Table 1). Both the Imageries were stacked in layers with the help of ArcMap Software. The stacked Imageries were merged with higher-resolution panchromatic Image (Band 8 for Both Landsat 7 and 8) so as to create a single higher-resolution $(15 \mathrm{~m})$ color image. The Bagmati river-basin boundary and the LRMP physiographic boundary layers were also used to define the study area extent.

\section{Object-based image classification}

Object-based image analysis (OBIA) is a technique developed to overcome the problem of traditional pixel-based image analysis. Pixelbased image analysis is based on the information in each pixel whereas the object-based image analysis is based on information from a set of similar pixels called objects or image-objects. OBIA reduces the local spectral variation caused by crown textures, gaps, and shadows. In addition to this, both spectral values and spatial properties, such as size and shape, can be explicitly utilized as features for further classification with spectrally homogeneous segments of images. In this process, spatially adjacent pixels are grouped into spectrally homogenous objects first, and then conduct classification on objects as the minimum processing units (Yu et al., 2006). Basically, there are two steps involved in OBIA. They are: (i) image segmentation to produce image objects (or segments) that are the relatively homogeneous groups of pixels, and (ii) image classification based on these image-objects (Dorren et al., 2003; Meinel and Neubert, 2004; Addink et al., 2007). Two image segmentation methods viz. Chessboard Segmentation Method and Multiresolution Segmentation are frequently used in OBIA. Chessboard Segmentation splits the pixel domain or an image-object domain into square image-objects whereas Multi-resolution Segmentation Method is an optimization procedure which locally minimizes the average heterogeneity of image-objects for a given resolution ( $\mathrm{Su}$ et al., 2009).

The Normalized Difference Water Index (NDWI) developed by Mcfeeters (1996) was used to delineate water features in the study. NDWI is derived using the principles similar to the Normalized Difference Vegetation Index (NDVI), and is defined as follows:

NDWI $=($ GREEN - NIR $) /($ GREEN + NIR $)$,

Where, GREEN is green band and NIR is near infrared band.

The reason behind the selection of these bands is to: (i) maximize reflectance of water by using green wavelengths; (ii) minimize the low reflectance of NIR by water features and (iii) take advantage of the high-reflectance of NIR from vegetation and soil features. As a result, water features have positive values whereas vegetation and soil usually have zero or negative values (Mcfeeters, 1996).

For both the Landsat Imageries of 2002 and 2014, the object-based image analysis was executed using the eCognition Developer 8.7 Software. The thematic layer of the study area was used in chessboard segmentation. Multi-resolution segmentation was performed at scale parameter of 20 with shape 0.5 and compactness 0.5 . Blue, Green, Red, Near Infrared, Short-wave Infrared-1 and Short Wave Infrared-2 bands were used in multi-resolution segmentation. The segmented images were classified into four land cover classes viz. i) Water ii) Sand and gravel, iii) Plantation potential (open area suitable for plantation) and iii) Others (forest, agriculture, built-up areas etc.) using the following parameters:

a) Mean brightness values,

b) Mean NDWI, and

c) Mean relation border to neighbors.

In the first step, sand and gravel were separated using the mean brightness values of the Images. NDWI was used to separate water bodies. All the water bodies outside the Bagmati River and

Table 1: Characteristics of Landsat image

\begin{tabular}{llllll}
\hline Satellite & Sensor & Path-Row & Date & Resolution (m) & Band \\
\hline Landsat 7 & ETM+ & $141-41$ & Nov 5, 2002 & 30,15 (Band 8) & Band 1 to 8 \\
Landsat 8 & OLI and TIRS & $141-41$ & Nov 28, 2014 & 30, 15 (Band 8) & Band 2 to 8 \\
\hline
\end{tabular}


its tributaries were categorized into 'Others' class. 'Plantation potential' was separated using mean relation border to neighbors. In this study, 'plantation potential' referred to the open area for plantation near the river (near water and sand and gravel classes). The remaining areas were categorized into "Others". The classified images were exported for further analysis.

\section{Visual interpretation and change detection}

To improve the classification, the classified polygons were visually interpreted with pansharped Landsat images of $15 \mathrm{~m}$ resolution in ArcMap 10. 'Union' function was applied on classified data to find out the changes between 2002 and 2014.

\section{Accuracy assessment}

Using new and innovative methodology which represents new area of ecological data, it is important to test accuracy of data being produced (Mathieu et al., 2007). A greater effort should be made for checking how much 'misclassification', e.g. omitted classification has occurred in course of land use classification. In the case of our study, the user's accuracy, the producer's accuracy, the overall accuracy as well as the kappa coefficient were used to test the accuracy assessment result.

Training-samples were selected systematically to assess the accuracy of classification. Point-grids at a spacing of $500 \mathrm{~m} \times 500 \mathrm{~m}$ were generated systematically over the entire study area. These point-grids were spatially joined using the already classified polygons. From each class, 10\% sample was selected; altogether, 243 sample points (6 from 'Water', 6 from 'Sand and gravel', 11 from 'Plantation potential' and 220 from 'Others') were verified with the help of high-resolution Image i.e. Google Earth. Some representative samples from the river reclamation areas were also verified through field observation.

\section{Social survey}

Focus-group discussion is one of the widely used methods to collect data in social survey. In this study, focus-group discussion was organized for identification of suitable species to rehabilitate the land reclamation areas through plantation. A total of four local-level focus-group discussions, 2 in Rautahat district and 2 in Sarlahi district, and one district-level focus-group discussion were organized in Rautahat district.

\section{Results and discussion}

The Landsat Images of 2002 and 2014 were classified into four types of land cover classes viz. i) Water, ii) Sand and gravel, iii) Plantation potential and iv) Others. The land cover maps of the study area for the years- 2002 and 2014 are presented in Fig. 3.

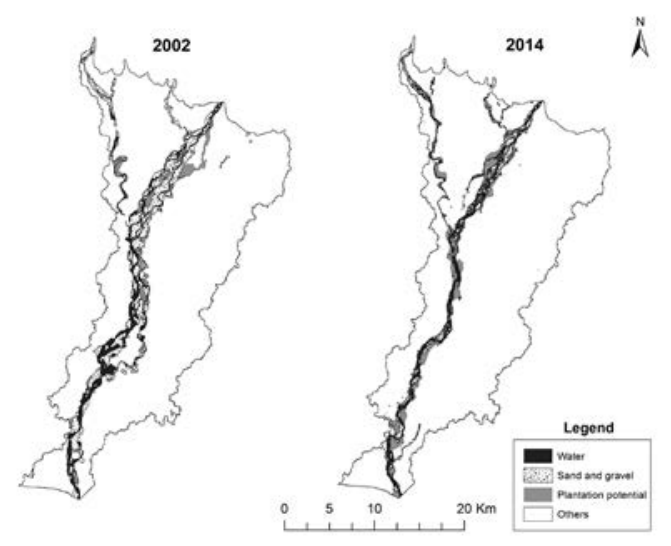

Fig. 3: Land cover map of the Bagmati riverbasin in the Terai region in 2002 and 2014

The change detection matrix showing the regional change in hectares between 2002 and 2014 are given in Table 2.

Table 2: Change detection matrix showing the change in the areas of the classes (in ha) between 2002 and 2014

\begin{tabular}{lrrrrr}
\hline \multicolumn{1}{c}{ 2002\20014 } & Water & Sand and gravel & $\begin{array}{c}\text { Plantation } \\
\text { potential }\end{array}$ & \multicolumn{1}{c}{ Others } & \multicolumn{1}{c}{ Total } \\
\hline Water & 628.84 & 347.99 & 495.60 & $1,114.60$ & $2,587.42$ \\
Sand and Gravel & 685.82 & 949.10 & $1,227.30$ & $1,981.60$ & $4,843.81$ \\
Plantation & 42.79 & 90.60 & 229.29 & 952.65 & $1,315.34$ \\
Potential & & & & & \\
Others & 298.01 & 203.84 & 346.66 & $51,685.09$ & $52,533.60$ \\
\hline Total & $\mathbf{1 , 6 5 5 . 4 5}$ & $\mathbf{1 , 5 9 1 . 5 3}$ & $\mathbf{2 , 2 9 9 . 2 5}$ & $\mathbf{5 5 , 7 3 3 . 9 4}$ & $\mathbf{6 1 , 2 7 9 . 7 8}$ \\
\hline
\end{tabular}


In this study, the land reclamation area referred to the area previously occupied by 'Water' and 'Sand and gravel' classes in 2002 and later converted into 'Plantation potential' and 'Others' classes in 2014. Altogether, 4,819.1 ha land was reclaimed within the study area over the last 12 years (2002-2014), out of which 2,708.8 ha and $2,110.3$ ha lands were reclaimed in Rautahat and Sarlahi districts. A total of 1,114.6 ha and 495.6 ha areas under 'Water' were converted into 'Others' and 'Plantation potential' classes, respectively (Table 2). Similarly, 1,981.6 ha and $1,227.3 \mathrm{ha}$ 'sand and gravel' areas were converted into 'Others' and 'Plantation potential' classes, respectively. The map of land reclamation area is presented in Fig. 4.
This study was confined to identification of land for plantation on the Bagmati river-basin in the Terai region of Nepal. Only the land reclamation study during the aforementioned period (20022014) is not enough to assess the actual area suitable for plantation, the existing plantation potential area should also be detected. In this study, the potential plantation area referred to the summation of the area of the reclaimed land, the area of 'Others' class converted into 'Plantation potential' class and the area that remained as 'Plantation potential' on the basin of the Bagmati River and its tributaries between 2002 and 2014. Over the period of 12 years, a total of 5,395 ha land was found to be potential for plantation (Table 3). Out of this, 3,054.12 ha area was found

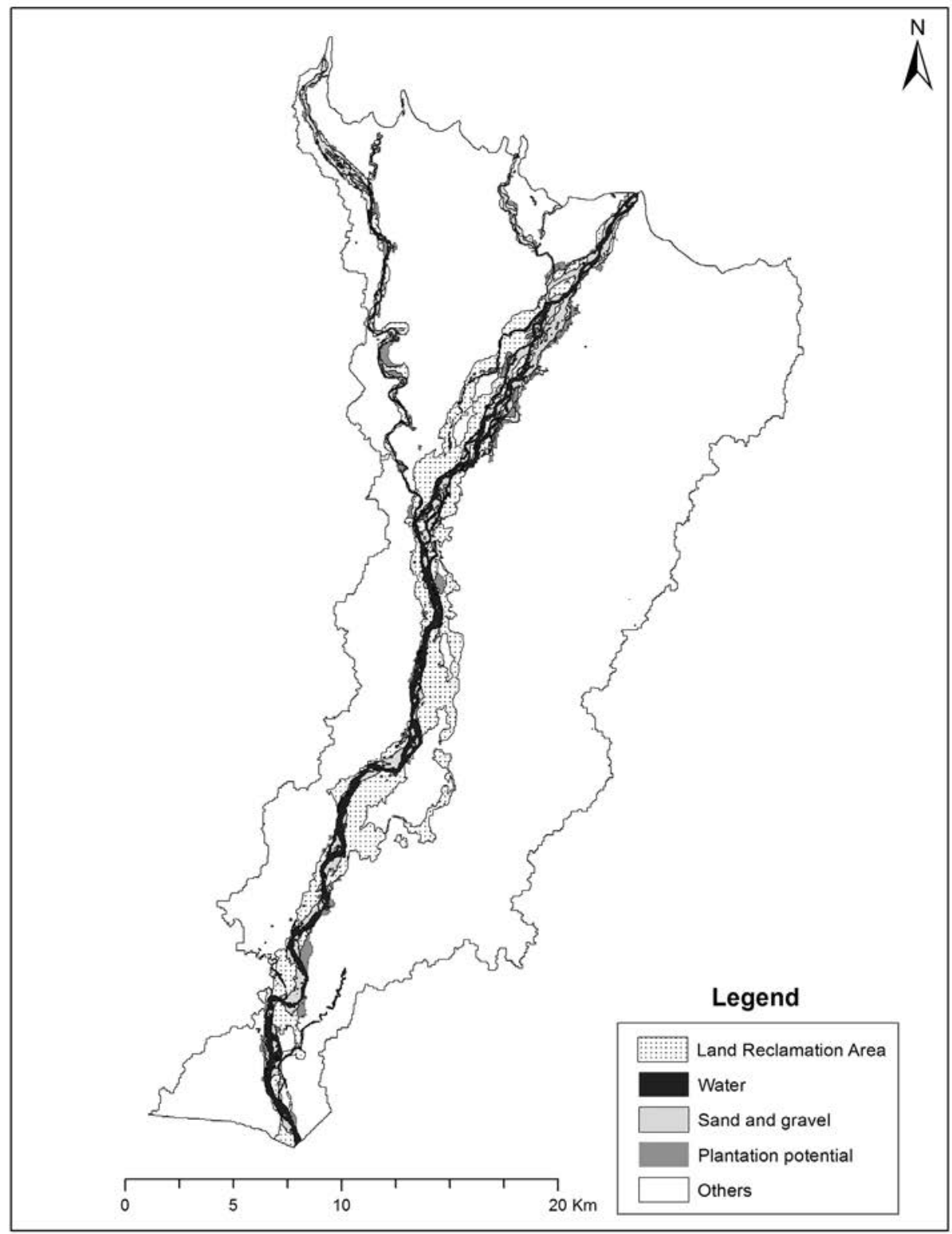

Fig 4: Map of the land reclamation area (2002-2014) 
to be potential for plantation in Rautahat district whereas 2,340.93 ha was found to be potential for the same in Sarlahi District.

Table 3: Potential plantation areas in the two districts

\begin{tabular}{llrc}
\hline \multirow{2}{*}{ District } & River & \multicolumn{2}{c}{$\begin{array}{c}\text { Potential plantation } \\
\text { area }\end{array}$} \\
\cline { 3 - 4 } & & Area (ha) & $\begin{array}{c}\text { Total area } \\
\text { (ha) }\end{array}$ \\
\hline Rautahat & Bagmati & $2,383.51$ & \\
& Paurahi & 572.46 & $3,054.12$ \\
& Chadi & 98.15 & \\
Sarlahi & Bagmati & $2,340.93$ & $2,340.93$ \\
\hline \multicolumn{2}{l}{ Total area } & $\mathbf{5 , 3 9 5 . 0 5}$ & $\mathbf{5 , 3 9 5 . 0 5}$ \\
\hline
\end{tabular}

in the selection of suitable species for plantation in such land reclamation areas.

\section{Accuracy of the classification results}

The overall accuracy in the case of the Classified Landsat 2014 Image was found to be $97.9 \%$ with a kappa coefficient of 0.89 (Table 4). In the classification, the producer's accuracy ranged from $75 \%$ in the case of 'Sand and gravel' class to $100 \%$ in the case of 'Water' and 'Others' classes whereas the user's accuracy was just the opposite, ranging from $83.3 \%$ in the case of 'Water' class to $100 \%$ in the case of 'Sand and gravel' class (Table 4).

Table 4: Accuracy assessment of the Classified Landsat 2014 Image

\begin{tabular}{|c|c|c|c|c|c|c|c|}
\hline \multirow[b]{2}{*}{ Classes } & \multicolumn{7}{|c|}{ Ground Truth } \\
\hline & Water & $\begin{array}{c}\text { Sand and } \\
\text { gravel }\end{array}$ & $\begin{array}{c}\text { Plantation } \\
\text { potential }\end{array}$ & Others & Total & $\begin{array}{c}\text { User's } \\
\text { accuracy } \\
(\%)\end{array}$ & $\begin{array}{l}\text { Error of } \\
\text { commis- } \\
\text { sion (\%) }\end{array}$ \\
\hline Water & 5 & 1 & & & 6 & 83.33 & 16.67 \\
\hline Sand and gravel & & 6 & & & 6 & 100.00 & 0.00 \\
\hline Plantation potential & & 1 & 10 & & 11 & 90.91 & 9.09 \\
\hline Others & & & 3 & 217 & 220 & 98.64 & 1.36 \\
\hline Total & 5 & 8 & 13 & 217 & 243 & & \\
\hline Producer's accuracy (\%) & 100.00 & 75.00 & 76.92 & 100.00 & & & \\
\hline Error of omission (\%) & 0.00 & 25.00 & 23.08 & 0.00 & & & \\
\hline Overall accuracy (\%) & & 97.94 & & $\mathrm{Ka}$ & pa Coef & ficient & 0.8904 \\
\hline
\end{tabular}

\section{Suitable species for plantation in the land} reclamation area

Focus-group discussions were organized among the local people for identification of suitable species for the purpose of plantation in the potential land reclamation areas. Most of the participants of the focus group discussions preferred Khayer (Acacia catechu), Sissoo (Dalbergia sissoo), Babul (Acacia nilotica), Gutel (Trewia nudiflora) together with Eucalyptus and Bambusa spp. for plantations in such land reclamation areas. The identified potential land reclamation areas were either public- or private-owned. In the private lands, the participants desired to adopt agroforestry model by growing watermelon, peanut and gourd together with trees. However, the ecological characteristics of tree species and the need of the local people should also be considered

\section{Conclusion}

This study indicates that the rivers in the Terai region change their courses over time periods, resulting in significant land reclamation. Over the last 12 years (2002-2014), a total of 4,819.1 ha land area was found to be reclaimed on the Bagmati river-basin within the study area. Such area could be planted with the suitable tree species along with the possible cash crops such as water melon, pea-nut and gourd. This will, no doubt, fulfill the local demand for fuel-wood and fodder on the one hand and provide income to the local people to some extent. However, further research should be done to determine suitable species and appropriate agro-forestry model before executing plantations over large land reclamation areas. Nevertheless, the proposed method is promising, and can be replicated to other river-basins too for 
mapping the potential reclamation areas. These results can be further improved by using highresolution satellite images together with sufficient field validation.

\section{References}

Addink, E. A., de Jong, S. M. and Pebesma, E. J. 2007. The importance of scale in objectbased mapping of vegetation parameters with hyperspectral imagery. Photogrammetric Engineering and Remote Sensing 72 (8): 905-912.

Adeniyi, P. O. and Omojola, A. 1999. Landuse/ landcover change evaluation in Sokoto-Rima basin of north-western Nigeria on archival remote sensing and GIS techniques. Journal of African Association of Remote Sensing of the Environment 1: 142-146.

Adhikari, B. R. 2013. Flooding and inundation in Nepal Terai: issues and concerns. Hydro Nepal 12: 59-65.

Dorren, L. K. A., Maier, B. and Seijmonsbergen, A. C. 2003. Improved Landsat-based forest mapping in steep mountainous terrain using object-based classification. Forest Ecology and Management 183: 31-46.

Mathieu, R., Freeman, C. and Aryal, J. 2007. Mapping private gardens in urban areas using object oriented techniques and very highresolution satellite imagery. Landscape and Urban Planning 81: 179-192.

Mcfeeters, S. K. 1996. The use of normalized difference water index (NDWI) in the delineation of open water features. International Journal of Remote Sensing 17 (7): 1425-1432.

Meinel, G. and Neubert, M. 2004. A comparison of segmentation programs for high-resolution remote sensing data. International Archives of Photogrammetry and Remote Sensing 35 (B): 1097-1105.
Paudel, A. 2001. Environmental Management of the Bagmati River Basin. In UNEP EIA Training Resource Manual: Case studies from developing countries, 269-279.

Su, W., Zhanx, C., Zhu, X. and LI, D. 2009. A hierarchical object oriented method for land cover classification of SPOT 5 Imagery. Wseas Transactions on Information Science and Applications 6 (3): 437-446.

Xian, G., Homer, C. and Fry, J., 2009. Updating the 2001 National Land Cover Database land cover classification to 2006 by using Landsat imagery change detection methods. Remote Sensing of Environment 113 (6): 1133-1147.

$\mathrm{Xu}$, H. 2006. Modification of normalised difference water index (NDWI) to enhance open water features in remotely sensed imagery. International Journal of Remote Sensing 27 (14): 3025-3033.

Yoon, G. W., Cho, S. I., Chae, G. J. and Park, J. H. 2004. Automatic land-cover classification of Landsat images using feature database in a network. International Archives of Photogrammetry Remote Sensing and Spatial Information Sciences 35 (2): 564-568.

Yu, Q., Gong, P., Clinton, N., Biging, G., Kelly, M. and Shirokauer, D. 2006. Object-based detailed vegetation classification with airborne high spatial resolution remote sensing imagery. Photogrammetric Engineering and Remote Sensing 72 (7): 799-811. 